Article

\title{
Visions and Expectations for the Norwegian Bioeconomy
}

\author{
Lillian Hansen * and Hilde Bjørkhaug \\ Centre for Rural Research, 7049 Trondheim, Norway; hilde.bjorkhaug@rural.no \\ * Correspondence: lillian.hansen@rural.no; Tel.: +47-97140144
}

Academic Editors: Antje Klitkou, Teis Hansen and Marc A. Rosen

Received: 30 November 2016; Accepted: 15 February 2017; Published: 24 February 2017

\begin{abstract}
Developing a future bioeconomy has become critical for three main reasons: (1) The need for sustainability of resource use; (2) The growing demand for both food and energy; and (3) The need to decouple economic growth from environmental degradation. As Zilberman observes, a transition to bioeconomy "is a continuing evolutionary process of transition from systems of mining non-renewable resources to farming renewable ones". Hence, to meet the challenges created by a growing dependence on non-renewable resources, radical changes are needed that involve more than development of or changes within the individual bio-based sectors. In line with emerging attention to the bioeconomy in Europe and elsewhere, great expectations towards the bioeconomy have been launched in high level industry and policy fora, as well as in resource-based economies such as Norway's. Grounded in theories of transition and transition management, this paper discusses the Norwegian biosector's expectations regarding a bioeconomy. Analyses are based on empirical survey data from biosector representatives. Findings suggest that there are clear differences between sectors in motivation for a future bioeconomy. A transition into a complete bioeconomy will demand a system shift and more cross-sectoral integration between these regimes than currently exists.
\end{abstract}

Keywords: bioeconomy; transitions; socio-technical regimes; visions; expectations; Norway

\section{Introduction}

Climate change, food security, health, industrial restructuring and energy security have all been conceptualized as the "grand" global policy challenges of our era (see e.g., Bugge et al. [1]). One solution developing over the last decade has been a suggestion of a paradigm shift towards a "globally integrated" bioeconomy [2], as a solution to particularly sustainable resource use, an increasing demand for food and energy, and the need to decouple economic growth from environmental degradation [3].

Norway has through a successful mining of North-sea oil built an economy dependent on fossil, non-renewable resources. Hence a green shift is necessary, and current policy makers see a national focus on the bioeconomy as part of this shift [4]. The Government's bioeconomy strategy emphases increased value creation and employment, reduction in GHG emissions and more sustainable utilization of resources as its overall ambition for the future bioeconomy. Particular ambitions relate to increased biomass production from both marine resources (fisheries and aquaculture) and major forest resources, as well as better utilization of waste from all bio-based industries, agriculture included. There are expectations that research and innovation will assist the bio-industries' ability in developing new knowledge and enhancing cooperation across sectors.

It has been stressed that to successfully achieve a sustainable development of the bioeconomy, there is a need for integrated policy schemes and activities based on engaging a broad range of stakeholders in an open and informed dialogue that includes both government and industry and a guarantee that they will support the innovation needed to advance the sustainable development 
of a bioeconomy [5]. Zilbermann et al. [6] however, state that a transition to a bioeconomy is not a quick fix but must be seen as "a continuing evolutionary process of transition from systems of mining non-renewable resources to farming renewable ones".

Several countries and jurisdictions have established policy strategies in order to promote and support the development of a bioeconomy, exemplified by the European Union where the bioeconomy represents a key pillar in its broader Horizon 2020 strategy. Other countries, like Canada, do not yet have an overarching bioeconomy strategy, but several competing strategies on sub-policy-frameworks [7]. When developing the Norwegian strategy, stakeholders were invited to participate [4]. Several reports have been requested to advise on this strategy, including from the Confederation of Norwegian Enterprise [8] and biosector organizations. The bioeconomy is argued to be part of a larger "green shift", as for example in the "Strategy for Green Competitive power" [9], a report delivered to the Norwegian Government in 2016. There are no doubt major expectations amongst policy makers, as well as industry organizations, regarding value creation from biobased production. How does this translate to the practitioners working in the "field", such as farmers, fishermen or owners of small companies producing or refining biomass? Are these just beautiful words on glossy paper or can they be operationalized for the transitions needed?

As explained by the European commission "The bioeconomy's cross-cutting nature offers a unique opportunity to comprehensively address inter-connected societal challenges such as food security, natural resource scarcity, fossil resource dependence and climate change, while achieving sustainable economic growth" [10] (p. 9). McCormick and Kautto argues that a strong commitment to sustainable development, that avoids the focus of short-term economic gains, is the key for a growing bioeconomy" [5]. However, a survey sent out by EC in 2011 [11], with over 200 submissions from organisations and individuals across most Members States, shows that a majority of respondents believe that there are a number of risks associated with the bioeconomy, including potential over-exploitation of natural resources and impacts on food security (p. 5). The analysis of the bioeconomy strategies of various countries by Staffas et al. [12] revealed that strategies for securing a sustainable biomass supply are absent from most national strategies. The ability to produce enough biomass was also one of the major uncertainties identified in the foresight exercise by the European Standing Committee on Agricultural Research [13].

The bioeconomy-concept has received a lot of scrutiny and critique for having a neo-liberal profit agenda [14,15] and that the bioeconomy only entails a "weak" ecological modernization [16] (p. 14) [17-19]. In this paper, we argue that finding values of sustainability and consideration for the environment in correlation with a belief in the bioeconomy, will be of importance for long-term policy planning. The need for giving greater attention to agency, power and politics in system transitions in general is argued by several researchers [20-22]: "System-level change is, by definition, enacted through the coordination and steering of many actors and resources, whether these are intended or emergent features of transformation processes"[20] (p. 1492). Firms and those who develop policy, are constantly confronted by economic and technological promises, creating new decision-making demands based on the interpretation of expectations in different forms [23]. This makes it very useful with analytical perspectives of expectations with which to make sense of future-oriented properties of innovation networks, especially given the highly contested character of expectations and futures [24]. This also goes for making sense of the expectations of larger networks or socio-technical regimes. Exploring expectations can therefore be a driving element in decision-making in firms and policy-settings by guiding or giving input to planning [25], but also for socioeconomic and advanced industrial change through transition management. Hence the research field of socio-technical transitions, together with the field of expectations, suggest that differing expectations towards a bioeconomy can cause challenges for a further transition.

In this paper, we ask: What expectations do Norwegian biosectors have regarding the bioeconomy and do expectations differ between sectors? How are biological resources, cooperation and concern for sustainability associated with these expectations and the sectors? 
Through studying the expectations and motivation in the biosectors regarding a future bioeconomy, we can show which sectors see themselves as more empowered. Using a survey questionnaire to engage stakeholders in the biosectors, we unveil different dynamics in expectations towards the bioeconomy and build knowledge of challenges and potentials in the management of a transition to a sector-integrated bioeconomy. The paper is grounded in a combination of transition theory and expectation studies and the following section develops the theoretical arguments informing the analysis. After the theoretical outline, the methodology is described, followed by a results section and finally discussion of expectations regarding a bioeconomy in Norway and the challenges a transition might face.

\subsection{Socio-Technical System Transitions and the Role of Expectations for Driving Change}

Change or transition processes can be studied from several perspectives [26-30], however the most commonly known is transition theory built on studies of system innovation processes [31], based on general insights on the connections between social and technical systems [32-34] (p. 176). Within such socio-technical systems [31] or industrial economies, sectors have developed separately. The result has been conceptualized as 'siloed', activity-based sectors such as e.g., science/expertise [35] agriculture [36] and forestry [37]. Each sector is engaged with separate problems, has different stakeholders and is governed by different policy-regimes.

To succeed with a bioeconomic transition, integrated development is required [38] across sectors, between multiple actors and between institutions throughout society (see e.g., Kleinschmidt et al. 2014 [37]). A shift to a complete bioeconomy would therefore demand cross-sectoral integration, or rather, a system change into a new socio-technical regime. "The socio-technical regime forms the 'deep structure' that accounts for the stability of an existing socio-technical system. It refers to the semi-coherent set of rules that orient and coordinate the activities of the social groups that reproduce the various elements of socio-technical systems" [39] (p. 5). These rules can consist of e.g., shared beliefs and values, routines and regulations [29] (p. 910). We argue that today's biosectors in Norway represent parts of separate socio-technical regimes. A transition to the bioeconomy need to overcome the strict rule differences and path-dependencies of the already existing regimes [29] (p. 910) [28,40] and to find space for collaboration across sectors.

The regime-concept in "socio-technical" introduces a structuralist element by assuming that actor behaviour is constrained by these rules, and that they are located at the collective level, which cannot easily be changed by micro-level activities such as individual action [41]. The regime concept can therefore help us pay attention to and investigate the "deep structures" behind present activities, such as trying to identify what are the shared beliefs and expectations, standardised ways of doing things and taken-for-granted rules of thumb [42,43]. As such, we are not applying the transition theory as a whole to our analysis, but rather applying the concept of socio-technical regimes to understand a segment of actor groups that is central to the bioeconomy: those working in the field of biosectors in Norway.

\subsection{Expectations Driving Transitions}

Whereas the theory of socio-technical transitions focuses on actual socio-technical and institutional path dynamics [26-30,44-46], transition management (TM) is about using the insights from transition dynamics for changing and governing problems in society. This can be done in several ways, but often involves creating a transition arena that includes all stakeholders in a field and trying to create visions and solutions together [47] (pp. 115-133). The TM literature places significant emphasis on the role of 'guiding visions' in affecting change, where ideas about how things might develop or what we wish for the future could serve as drivers for the future $[20,30,48]$. According to Smith, Stirling and Berkhout [20] visions or expectations about future system innovations can have several important functions: (1) giving a realm of plausible alternatives; (2) showing the problems that need to be solved; (3) providing a stable frame for thinking in the same manner or monitoring progress; (4) binding 
certain types of actors into networks, and excluding others; (5) and becoming a symbol used for attracting resources outside the core of a regime. We argue for the need for TM to include visions and expectations to a greater extent, reaching out to a broader set of stakeholders, before entering the smaller transition arena.

Expectations are understood as means, both intentional and implicit, of individual or collective actors to refer to the future in real time in a way that has a resonance on how the future might look like [49]. More explicitly, Van Lente [50] (p. 772) describes expectations as "statements about the future", which can be either be oral or written, and that circulate. They can take many forms, as positive promises or negative warnings and they might be concrete or rather abstract. The field of sociology of expectations explores how expectations in science and technology are structured, how they grow and change or disappear, and how they affect decision-makers and businesses [23,24,51,52]. Van Lente [51] has presented expectations as a key driver for current technological change. One of the explanations for such effects, lies in what Guice [53] calls the mechanism of self-fulfilling prophecy: By talking about an issue in a certain way, because of the assumptions and latent ideas in arguments, support is given to a particular way of seeing an issue and also defines the issue in the first place [54,55]. This gives expectations their "performative" character [50].

Understanding the expectations of different members of a system or regime for a possible change in the future therefore becomes of utmost importance. In this paper, we do this by focusing particularly on expectations where we can identify vital parts of the different regimes of biosectors and their motivation for change towards a future bioeconomy.

\section{Methods}

\subsection{Survey of the Bioeconomy}

To grasp the enormous complexity and number of stakeholders involved in a potential bioeconomy transition, we chose a survey-based exploratory approach as a feasible way to identify individual characteristics, resource availability and expectations towards the bioeconomy on the part of those working in "the field" of the biosectors, such as farmers, fishermen, and owners of industrial corporations or small biotechnological firms. The survey was sent out during Spring 2016 via e-mail to the owners of companies/businesses expected to be a part of the biosectors in Norway. As the bioeconomy is a concept under development in Norway, the population could be argued to be unknown. Hence we decided to send the survey to a broad sample. The questionnaire was designed, developed and sent out using the software MI Pro Research Studio 6 via e-mail. The web-format of the software made it possible for respondents to use their tablet, mobile or computer.

The sectors were chosen according to what the main activity of their firm was, based on EU NACE-code (see e.g., [56]) standards for industries having a relationship with biomass production and/or using and/or refining biomass. The main sectors with respondents to the survey were the primary industries of agriculture, forestry and fisheries; electricity, gas, steam and hot water; water, sewer and renovation; building and construction; merchandising and repair of vehicles; commercial services; research and development and technical service. One caveat is that other stakeholders and actors related to the bioeconomy, such as policy-makers, consumers and a large part of the research community are not included. However, the scope of the project put limitations to this. This will also be part of a later stage of our project. We were nevertheless able to reach out to a very broad spectrum of the industry and primary sectors.

The basic unit of the survey is the business/firm. The total population was 136,635 registered firms, where 25,027 had email addresses and these were chosen for the study. An analysis of this sample compared to the population revealed no evidence to assume that it was not representative. There was no random sampling, rather sending the survey to the total available population with valid e-mail addresses. Of these a sample of 1315 responded, which means a total response rate of 5.23 percent. Here, we could observe possible non-response bias. This happens when some members of 
the intended study population fail to provide required data (the nonresponders), and when those who respond are not representative of the entire study population [57]. However, as we are actually working from a very explorative design, reaching out to a very broad group, it is more interesting to look at who actually did respond. Even with a low response rate the responses in each sector do essentially mirror the proportion of firms in each sector of the total population. The sector-wise response rates ranged from approximately five percent for agriculture and forestry, to as low as 0.89 in the commercial service sector. In addition, fisheries were somewhat lower represented with 2.83 percent. However, the percentage representation of the different sectors in the gross sample (those with an e-mail address) and the net sample (those who answered) compared to the total population are generally consistent, except some sectors being somewhat overrepresented, like industry, and some underrepresented, like fisheries. As Table 1 below show, the net sample of agriculture is generally mirrored in the population sample. The same goes for forestry.

Table 1. Distribution of the sectors, in the population, gross sample and net sample.

\begin{tabular}{cccc}
\hline Sector & Population & Gross Sample & Net Sample \\
\cline { 2 - 4 } & $\mathbf{\%}(\boldsymbol{n})$ & $\mathbf{\%}(\boldsymbol{n})$ & $\mathbf{\%}(\boldsymbol{n})$ \\
\hline Agriculture & $57(78,546)$ & $45(14,059)$ & $55(724)$ \\
Forestry & $14(19,670)$ & $12(3859)$ & $15(195)$ \\
Fishery & $8(10,713)$ & $6(1880)$ & $3(33)$ \\
Industry & $9(12,762)$ & $17(5195)$ & $11(147)$ \\
Water/construction & $3(4560)$ & $6(1744)$ & $6(80)$ \\
Merchandising and commercial services & $5(7236)$ & $9(2707)$ & $5(60)$ \\
Research and development and & $2(3148)$ & $5(1515)$ & $6(74)$ \\
technical service & $100(136,635)$ & $100(30,959)$ & $100(1313)$ \\
Total & & &
\end{tabular}

Further considering the representativeness of the survey we are actually not working from a sample-based statistical theory. Sample-based statistical theory can be useful for generalization purposes if the intention is to map certain relationships in a population based on a probability sample. However, if the goal is to study relationships between variables, this prerequisite of a probability sample is not needed according to Aaberge og Laake [58]. Here, model-based statistical theory can be used instead. The only assumption here is that there has to be a certain degree of variation in the variables. Estimations and testing of structures (statistical relationships) are therefore not connected to the probability-sample theory. In other words, we cannot argue that the results of the survey represent the total population of the industries in Norway. However, we can argue that there is a likelihood of finding the same group-variation in the population.

It is problematic to assume that the population of firms that we identified with a relationship to biomass would have a relationship with the bioeconomy. Only the firms themselves could know if they are at the given time of our survey relevant to the bioeconomy. We do assume that a large proportion of companies did not answer because of this. We got feedback from several who didn't see themselves as relevant for the survey. This might be because they are too far down the value chain, or the categories for answers to the questions about biomass didn't capture their activity. Other non-response issues include difficulties with attracting people engaged in seasonal work or who are fishing far out to sea without regular access to a computer. Through e-mail communication with non-responders we learned that some of the firms that received the survey hadn't even started up, or they had been closed down, or some of the owners had retired.

Given the exploratory design of the study and the non-response issues related to the survey, whose visons are expressed in this study? Who then are the "bioeconomists"? We will argue that our sample of 1315 respondents can be seen as self-selected representatives of the future bioeconomy and hence they give the "best" estimate for our research questions on current expectations for the Norwegian bioeconomy. 


\subsection{Descriptive Data Analysis Method}

Descriptive statistics were used to characterize the survey respondents and assess general trends among these representatives of the bioeconomy on owner/user and business characteristics, relationship to bio-resources, values and expectations. Because the factual sample sizes in the sectors are roughly proportional to the number of bio-workers in each sector, the usual formulas for $p$-values and standard errors are valid. Cross tables and $t$-tests were conducted to explore how these representatives of the bioeconomy expect and evaluate future use of biomass and how their own company and activities will be part of future developments in the bioeconomy within and across the sectors explored.

\subsection{Business Characteristics}

The EU-NACE codes are not used in analysis. We have chosen to use the businesses own placement in sectors based on the following categories: (1) agriculture; (2) forestry; (3) fisheries; (4) aquaculture; (5) manufacturing and processing; (6) transport, retail and distribution; (7) biotechnology; (8) research and development; (9) public services; (10) other. The categories were in the survey developed out of bioeconomy-sectors listed by the European Commission's Bioeconomy Panel (see EU 2012:16), and adding to this the two categories transport, retail and distribution and public services. Among the 3 first categories the majority of businesses are in primary production.

Most of the respondents represent businesses organized as sole proprietorships (63\%) and public limited companies (approximately 20\%). Most respondents are CEO/Directors of the company (75\%), while $8 \%$ are middle managers and $5 \%$ are employees with no managerial responsibility in the company. Almost $12 \%$ answered "other" about their role. This could perhaps be a secretary, someone outside who knows the firm well, a board member or a spouse. The average age was 51 years old, with a median of 52, showing that there were not any extreme values. The education level varied within sectors, with e.g., $37 \%$ of those from Agriculture listed with Secondary school as their highest level of education and $58 \%$ of them with university education.

\subsection{Business Resources, Cooperation and Concept of Sustainability}

Resources are measured asking the question of: "Which of the following biological raw materials or products, does the company have access to?" They could answer one or several of the following: Forest/timber, Plant/crops, Animals or animal products, Fish/seafood, Macroalgae (seaweed/seagrass), Microalgae, and/or other biological raw materials or products. The three last had too few respondents to be included.

Cooperation with other sectors was measured with the following question: "Which sectors/industries does your business cooperate with today? (e.g., product development, sharing equipment/services, utilization of residual raw materials/energy, research and development, etc.). (One, several or no answer is possible)". Here each respondent could answer all of the sectors: agriculture, forestry, fisheries, etc., but also cooperation with investors. Both the resource variables and the cooperation-variables are dummy variables.

Sustainability-attitude was measured through a combination of several statements, with the question starting like this: To what extent do you agree or disagree with the following statements about nature and people? The statements that were combined were: "Nature's adaptability is so good that it can withstand the impact of industrial nations", "The ecological crisis that afflicts us is greatly exaggerated," "If the trend continues this way, we will soon experience ecological disaster". The respondents could rate the answers from completely disagrees to completely agrees. The variable used in our analysis then measures a general attitude that nature can withstand anything — which then represents an unsustainable attitude. 


\subsection{Measuring Expectations to the Bioeconomy}

Expectations towards the bioeconomy are measured through the question: "To what extent do you agree or disagree with the following statement: My business will continue to be an important contributor to the bioeconomy in the future". This question is measured using a scale from 1 to 5 with completely disagree to completely agree.

For exploring the respondent visions and expectations about the biomass potential in the future, four variables were developed. The phrasing on these were: "On a scale of 1 to 7 , how do you think the production of biomass will be in about 15 years, compared with today?" Respondents were asked to evaluate the question connected to (1) biomass for food; (2) biomass for energy; (3) biomass for purposes other than food and energy and (4) production of biomass in Norway (in general).

In addition to these, a combined measure focusing on the supply and demand side of biomass in Norway using the (1) production of biomass in Norway (in general) and (2) demand for biomass in Norway (in general). These two questions were then put together for a joint measure of biomass potential in Norway.

\subsection{Outline of the Research Questions}

Based on survey results for the variables described above, two main research questions guide our analysis: (1) what expectations do our respondents from the biosectors have about the bioeconomy and do they differ between sectors?; and (2) how are biological resources, cooperation and concern for sustainability associated with these expectations and sectors?

Are there converging beliefs/expectations about the future bioeconomy, and what are the motivations for the differences? Do the representatives of the biosectors see themselves as contributors in the future bioeconomy? What uses of biomass have more potential from the biosectors' perspective: food, energy or alternative uses? When controlling for individual resource factors of age, education level and income, are high expectations to the bioeconomy determined by special types of resources and sector-collaboration today?

We argue that each biosector in Norway represents its own regime, with its own rules and way of operating in "the field" of the sector. In this paper, we will measure the validity of this assumption through comparisons between sectors' expectations of the bioeconomy. We argue that future development of the bioeconomy would entail a larger integration of shared beliefs and expectations across the biosectors, and represent a socio-technical system. Strong sector differences in expectations towards a bioeconomy might indicate potential lock-in that challenges development of the bioeconomy in Norway.

To measure how different resources variously affect or generate expectations we ask: what resources give the highest expectations to the bioeconomy? Biomass consists of many types of resources that can be put to use for a broad spectrum of purposes. Measuring which of these has the most potential, according to our respondents, can help in long-term planning and knowledge building around the bioeconomy. Here it is especially interesting to compare how the different resources are used or seen as important across the different sectors.

Through measuring which sectors cooperate today, and who they wish to cooperate with in the future, we can provide important indications of future challenges. Some sector-cooperation can be argued to have a greater impact on expectations for the bioeconomy. In addition, the lack of potential for cooperation could represent a possible bottle-neck, knowledge gap or path-dependency within the sectors.

As shown above, while the bioeconomy concept has received a lot of scrutiny and been criticized as another way of exploiting resources for economic profit, others have major ambitions for the bioeconomy being part of a "green shift" in the economy. Finding that values of sustainability and consideration for the environment highly correlate with a belief in the bioeconomy will be of importance for the long-term policy planning the bioeconomy demands.

The next section of the paper shows the results of our analysis. 


\section{Results}

\subsection{Expectations to the Bioeconomy and Level of Biomass Production within a Bioeconomy Development}

On the dependent variable of expectations regarding own contribution in the bioeconomy, the mean value is 3.55 ( 1 strongly disagree to 5 strongly agree). This means that the variable is positively skewed. The same pattern was found when checking the assumption if the residuals are normally distributed: a slight right skewness. We interpret this to be rather small and do not make any changes in the data to correct for this.

Figure 1 displays average scores on variables on expectations about the bioeconomy and biomass production.

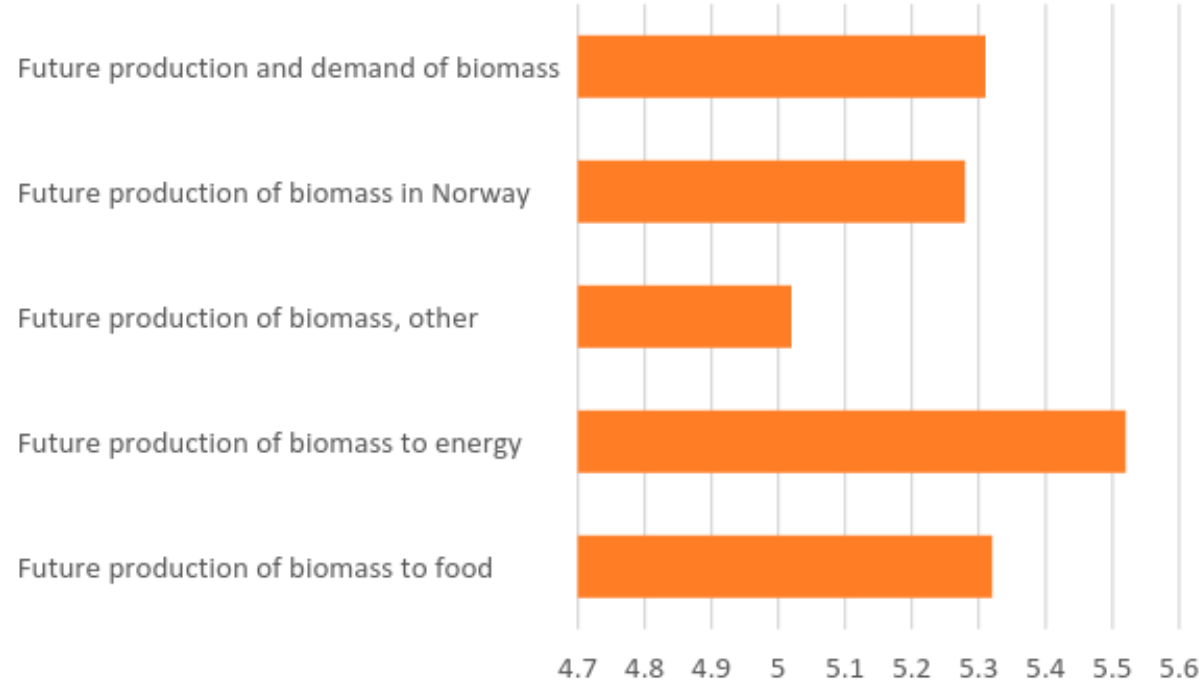

Figure 1. Expectations about future production of biomass.

In general, we see a rather high mean for all questions, especially for biomass to energy use. Biomass used for other than food or energy has the lowest mean.

When looking at the future expectations questions for each sector some more nuance appears. Table 2 shows how the means differ between the sectors.

Table 2. Beliefs and expectations towards biomass and the bioeconomy by sector.

\begin{tabular}{|c|c|c|c|c|c|c|}
\hline Main Sector Means & $\begin{array}{l}\text { ContrFuture } \\
\text { Bioeconomy }\end{array}$ & $\begin{array}{c}\text { FutureProd } \\
\text { BioFood }\end{array}$ & $\begin{array}{c}\text { FutureProd } \\
\text { BioEnergy }\end{array}$ & $\begin{array}{l}\text { FutureProd } \\
\text { BioOther }\end{array}$ & $\begin{array}{l}\text { FutureProd } \\
\text { BioGenNor }\end{array}$ & $\begin{array}{l}\text { FutureBio } \\
\text { ProdDem }\end{array}$ \\
\hline Agriculture & 3.66 & 5.21 & 5.48 & 4.88 & 5.20 & 5.27 \\
\hline Fishery & 3.70 & 5.56 & 5.26 & 4.26 & 5.30 & 5.28 \\
\hline Aquaculture & 4.12 & 6.29 & 5.25 & 4.62 & 6.06 & 6.00 \\
\hline Manufacturing/processing & 3.29 & 5.47 & 5.54 & 5.38 & 5.36 & 5.35 \\
\hline Biotechnology & 4.24 & 5.87 & 5.53 & 5.73 & 5.87 & 5.83 \\
\hline Research and development & 3.16 & 5.55 & 5.38 & 5.26 & 5.39 & 5.36 \\
\hline Public services & 3.57 & 5.48 & 5.69 & 4.88 & 5.41 & 5.48 \\
\hline Other & 2.93 & 5.28 & 5.23 & 4.95 & 5.08 & 5.10 \\
\hline Total mean & 3.55 & 5.32 & 5.52 & 5.02 & 5.28 & 5.31 \\
\hline
\end{tabular}

A bivariate regression with $t$-test of the different sectors against agriculture as reference category (table not shown) revealed some significant $(p<0.10)$ sector differences. Sectors such as manufacturing/processing, transport/retail, biotechnology, research and development, fisheries and others were significantly different. The other sectors do not significantly vary from the agriculture 
sector. The lack of statistical significance can for some of these sectors be explained by size or homogeneous expectations. On direction of difference the aquaculture (not significant) and biotechnology are more positive than agriculture, while all the other sectors are more reticent in their expectations for themselves in the future bioeconomy. The most negative beta coefficient is found for the transport sector. For expectations about future production of biomass to food (FutureProdBioFood) the highest mean is again found in the aquaculture and biotechnology sectors. The lowest is found in agriculture. In the bivariate regression with $t$-test of the different sectors against agriculture as the reference category we found that aquaculture, manufacturing and biotechnology sectors are positive and significantly different from agriculture.

For expectations about future production of biomass to energy (FutureProdBioEnergy) the largest means are found in the forestry and public services sectors, and the lowest for other and aquaculture sectors. However, no significant differences were found in the bivariate regression analysis.

For expectations about future production of biomass to other uses (than food and energy) (FutureProdBioOther) we see the highest mean for the biotechnology sector and the lowest for the fishery sector. Like the previous question, no significant differences were found.

On the question on biomass production in general (FutureProdBioGenNor) Table 1 shows more variation between the sectors. The mean of the aquaculture sector is the highest, and second is the biotechnology sector. The lowest means are found in the transport, retail and distribution sector and in the "others" sector. The bivariate regression analysis with $t$-test showed significant positive results for the forestry, aquaculture and biotechnology sectors when compared to the reference category Agriculture.

For the combined variable on production and demand for biomass in the future (FutureBioProdDem), the highest mean is again found in the aquaculture sector, while the lowest is transport and "other". With the bivariate regression with t-test, the aquaculture, biotechnology and forestry sectors are significantly more positive than agriculture.

\subsection{Identifying Drivers and Barriers to a Positive Outlook of the Bioeconomy-A Multivariate Regression Model}

What are the characteristics, or rather, the resources and attitudes that are associated with expectations about a bioeconomy, controlling for the sectors? In other words, what factors can seem to affect a potential sustainable transition towards a bioeconomy? To identify potential drivers and barriers to beliefs and expectations about a bioeconomy, we quantified the degree of association between several characteristics of the businesses from the biosectors. Among these are respondents' age, level of education, what sectors they represent, what type of funding/capital they had access to for innovation, what biological resources they had access to, who they cooperate with today and their attitude towards nature and sustainability.

The preliminary models testing for the effect of age, education, income and access to different types of funding showed no significant results, indicating that other factors are explaining variation across expectations to the bioeconomy. We will argue that these expectations are framed by certain combinations of resources, sector membership, cooperation and latent attitudes on sustainability.

Table 3 shows the results and significance of adding blocks of variables in a stepwise regression of 4 models. The results with all variables are shown in Table 4. In model 1 the regression analysis contains a dummy set for which sector the business is from, described earlier in the bivariate regression. In model 2, access to biological resources has been added: forest/wood, plants, animals, fish and "other". All except animals as a resource have statistically significant results with a positive effect. These variables are adding five percent explanation power to the model (Table 3). In model 3, different dichotomy variables measuring cooperation between sectors have been added. Cooperation with several sectors is positive on the expectation about the Bioeconomy: Cooperation with agriculture, forestry and research clearly have the strongest correlation with the dependent variable. The effect of wood/forest as a resource loses its effect when cooperation variables are added. In the final model (4 in 
Table 3, Table 4 full analysis), the variable measuring attitude towards nature has been added. Now the sectors transport, retail and manufacturing are no longer significantly different from agriculture when new variables are added, however the forestry sector is. The variable added, on nature values, is negative, meaning that a belief that nature can withstand anything is negatively correlated with expectation about the bioeconomy.

Table 3. Results from the significant stepwise regression of associated variables on expectations.

\begin{tabular}{ccccc}
\hline & Model 1 & Model 2 & Model 3 & Model 4 \\
\hline $\begin{array}{c}\text { Number of } \\
\text { observations }\end{array}$ & 1099 & 1099 & 1099 & 1099 \\
\hline Types of variables & Sectors & $\begin{array}{c}\text { Access to resources: Wood, } \\
\text { Plants, Animals, Fish, Other }\end{array}$ & $\begin{array}{c}\text { Cooperation with } \\
\text { each sector }\end{array}$ & $\begin{array}{c}\text { Attitude towards } \\
\text { nature }\end{array}$ \\
\hline Prob > F & 0.00 & 0.00 & 0.00 & 0.00 \\
\hline R-squared & 0.0482 & 0.0987 & 0.1799 & 0.2014 \\
\hline Adj R-squared & 0.0404 & 0.0871 & 0.1616 & 0.1828 \\
\hline
\end{tabular}

Table 4. Multivariate regression analysis of associated variables on contribution to the future bioeconomy.

\begin{tabular}{ccccc}
\hline Contribution to the Future Bioeconomy & Coef. & Std. Err. & $\mathbf{P}>\boldsymbol{t}$ & Beta \\
\hline SectorForestry & 0.3086641 & 0.1184941 & 0.009 & 0.0925478 \\
SectorFisheri & 0.4601266 & 0.2785138 & 0.099 & 0.0592965 \\
SectorAqua & 0.3595967 & 0.3579285 & 0.315 & 0.0353787 \\
SectorManufactProcessl & 0.0562456 & 0.1399723 & 0.688 & 0.013466 \\
SectorTransport/Retail & -0.2478919 & 0.1901758 & 0.193 & -0.0384041 \\
SectorBiotechnology & 0.7828823 & 0.2843118 & 0.006 & 0.0819219 \\
SectorResearch\&Dev & -0.3724596 & 0.2097966 & 0.076 & -0.0562163 \\
SectorPublicServ & 0.1411579 & 0.22511 & 0.531 & 0.0188601 \\
SectorOther & -0.2463761 & 0.1420419 & 0.083 & -0.0555056 \\
ResForWood & 0.1090096 & 0.0871841 & 0.211 & 0.044567 \\
ResPlants & 0.2918529 & 0.0926666 & 0.002 & 0.1220088 \\
ResAnimals & -0.086282 & 0.0937744 & 0.358 & -0.0307129 \\
ResFish & 0.4463691 & 0.1793093 & 0.013 & 0.0846251 \\
ResOther & 0.1798223 & 0.1535027 & 0.242 & 0.0329582 \\
CoopAgri & 0.4175784 & 0.0917441 & 0.00 & 0.168511 \\
CoopForest & 0.3392904 & 0.0796035 & 0.00 & 0.1434762 \\
CoopFishery & 0.0653822 & 0.1826167 & 0.72 & 0.0134483 \\
CoopAqua & 0.0011873 & 0.1895234 & 0.995 & 0.0002287 \\
CooManuProcessing & 0.0602297 & 0.0775704 & 0.438 & 0.0244641 \\
CoopBiotech & 0.2169488 & 0.138979 & 0.119 & 0.0475156 \\
CoopResearch & 0,3270734 & 0.0931494 & 0.00 & 0.1173906 \\
CoopPubServ & 0.2009068 & 0.0898073 & 0.025 & 0.0722051 \\
CoopInvest & 0.1443567 & 0.1676242 & 0.389 & 0.0252636 \\
CoopTransport & 0.1033049 & 0.0784455 & 0.188 & 0.040747 \\
NatureWithstands & -0.1984905 & 0.0369048 & 0.00 & -0.1513888 \\
_cons & 3.155955 & 0.1354461 & 0.00 & \\
\hline
\end{tabular}

However, when adding interaction variables to control for conditioned effects, we found some more nuance to our data. This will be further discussed below in relation to the theoretical approach. 


\section{Discussion}

\subsection{Expectations to the Bioeconomy: Sector Differences}

Dynamics of socially shared expectations are argued to affect the emergence of new socio-technical configurations or systems [24,59-63]). Conversely if relevant sectors have significantly different expectations for the future, this can be a potential obstacle to achieving wanted changes, as it can make policy planning more difficult. In this paper, we have empirically studied what expectations respondents from the biosectors have for the bioeconomy and how they differ in their expectations.

The analysis revealed clear sector differences regarding expectations for the bioeconomy, strengthening the assumption that the current division of sectors with a relationship to biomass represents different socio-technical regimes. These differences challenge shared expectations at the system level, raising potential barriers for the management of a bioeconomy transition.

Our analysis showed that the aquaculture sector has higher expectations for the bioeconomy, compared to agriculture. The same goes for biotechnology and forestry. In the final regression model also fishery was significantly $(p<0.10)$ different. Aquaculture sees a high potential for large-scale food production, as the current Government has an aim to increase production in this sector [64].

Our findings on the expectations regarding biomass for food and in general for demand and supply in the future further suggest a clear tendency for the agriculture sector to be less positive than several of the other sectors and also more reluctant in their expectations for themselves compared to the primary sector such as forestry and aquaculture. This is a potential problem, as the agriculture sector is an important contributor to domestic food production, a fundamental product also in a bioeconomy. The transport sector seems to have low expectations for the bioeconomy as well. These findings lost significance, however, when other factors were controlled for in in the multivariate regression analysis.

Agriculture is a political industry in Norway and, unlike other industries, it produces for a protected domestic market and is expected to achieve such policy goals as food security, food sovereignty, rural settlement and employment, and the maintenance of agricultural land and cultural landscapes. Farsund argues that the main reason for stability in this sector is because of the agricultural agreement, which serves as a robust and flexible institution [65]. However, the OECD argues for a greater exposure to market signals [66] (p. 112). Almås argues that the Norwegian agriculture model is under pressure, and with current policies the agriculture sector will not be able to deliver the increased food production that a united Storting wants [67] (pp. 68-71). It can be argued that the agriculture sector to a larger degree is "under the mercy" of the Government compared to the other biosectors. This could explain the lower expectations of the agriculture sector compared to the other sectors when it comes to involvement with the bioeconomy.

Brandlistuen [68] argues that Norway has defensive interests regarding the agriculture sector, but offensive interests for the fishery-sector, which is visible in previous negotiations of WTO. There is therefore a lack of a unified actor for these two food-producing sectors. As the report of Falk-Andersson et al. [64] has shown, the potential for increased production differs between the sectors, and as the bioeconomy is dependent on renewable resources, this shows the necessity of joint policy planning.

The transport, retail and distribution sector is worth a further comment. This sector has low expectations for themselves as contributors to a future bioeconomy (however, not in the final regression model when controlling for all other variables mentioned). It could be argued that the transport, retail and distribution-sector differs from the other sectors, as it is not a producer of materials or biomass, and is also very diverse. It is, however, a potential large client of biomass-products, or fossil fuel products (if transport). Not least, it intertwines with several sectors in Norway. The need of a stable and reliable policy-framework will be crucial for the ability of the transport sector to operate in an environmentally friendly way. The fight over the biodiesel-fee in the Norwegian Government and Parliament in 2009, created a lot of uncertainty and is not easily forgotten [69] (pp. 4, 29). In addition, new research on the viability of different types of biomass keeps adding to our knowledge. e.g., a 
new report on biodiesel [70]) concludes that first generation biodiesel from plants, especially palm oil leads to much higher emissions than traditional (fossil) diesel. The biodiesel fee has been removed in Norway since 2015. However, there always looms a possibility that the Government can change the fees yet again, making the framework for the transport sector especially vulnerable.

Research and development was a sector less positive than agriculture $(p<0.10)$. These are interesting findings, but one could also argue that it is a sector in need of clear coordination and one that further strategizing might contribute to.

\subsection{Resources as a Driving Factor}

By analysing the association between sectors' different biological resources, sector cooperation and the expectation and motivation for being a contributor to the future bioeconomy, our findings suggest a transition potential particularly with access to some types of resources. At first glance all biological resources are contributing positively, giving those businesses with access to these a stronger correlation with positive expectations to the bioeconomy, than those who do not have access to these resources. After controlling for several variables, including the sector of the business, some of the variables lose their effect and the results become more nuanced: having access to fish and plants have a higher association with the bioeconomy. Both of these resources in general represent food security [71]. However, their residues can also be used for other products, such as biogas (e.g., [72]) and fish/animal feed (e.g., [73]). The potential of access to fish and plants for furthering a bioeconomy we would argue lies in their dual-usage potential in a circular bioeconomy [74].

However, interestingly, access to wood did not have a significant effect. The forest and wood as a resource can represent high value products for the bioeconomy, as demonstrated by, among other things, the advanced biorefinery Borregaard [75]. Policies regarding the end-products from wood are still under a lot of debate, as e.g., bioethanol production (from among other things wood) has been argued not to be economically feasible [76,77]. However, with combined biogas and bioethanol production in a biorefinery there is great potential for improving the overall energy balance $[75,76]$. Concerns about extracting these resources are also an issue, relating to carbon storage in the soil and forest-based nature experiences [78-81]. However, another simpler explanation why access to wood is not significant might lie in the fact that the wood market is not as developed as the market for fish and plants. It is less mature, both as an input factor and in its current need for technological solutions for processing sustainable end-products.

\subsection{Cooperation as a Driving Factor}

To be able to achieve a system level shift, we need better integration between the sectors related to biomass. Our analysis showed that cooperation with agriculture was more positive for the transport sector, retail and distribution, and research, compared to the reference category agriculture when checking for interactions. This again shows the importance of the connection of the transport sector with other sectors. The sector alone is more negative to the bioeconomy than most of the other sectors, as seen before. Both transport and research sectors can be argued to be dependent on the primary sector agriculture for the future of the bioeconomy. Cooperation with the forestry sector had an especially strong effect if the business was from manufacturing/processing. However, this was the opposite for businesses from public services when running more regression models including interaction-variables. Here we might see a potential barrier between forestry and public service sector. The reason for this barrier might lie in the debate about ownership of the forestry. Based on research from Follo [82], among others, Norway is the country in Europe with the highest amount of privately owned productive forest [83]. The public service sector might feel too far distanced from the actual businesses of forestry. As we saw, the manufacturing sector was more positive to the bioeconomy when cooperating with forestry (regression with interaction-variables), one reason perhaps being their proximity, industry areas being at the outskirts of cities, while public services often lie at the heart of cities and towns. 


\subsection{A Sustainable Transition?}

Some academic work accentuates the need to see the bioeconomy in a wider political framework. How is it answering the challenges facing the current neoliberal-capitalist accumulation regime, which it is also considered to reproduce [14,15]? This is part of a wider critique aimed at the "bioeconomic project". Work by Sodano [84] accentuates the need to reveal the ideological stances behind the bioeconomy-discourses. After analysing several documents either pro or against the bioeconomy, he finds that the pro-documents, are driven by a form of techno-neo-liberalism, for forging new forms of capital accumulation.

Our analysis showed a general tendency to be more concerned for nature if the business also was positive towards a future bioeconomy. The variable "naturewithstands" can be interpreted as nature values, and with this variable connected to sustainability of nature, sustainability concerns on nature's final capacity are being positively correlated with expectations to own contribution to the bioeconomy. However, when checking if this effect was conditional on the sector the business is from, we found significant results that the industry sector was somewhat less concerned about nature vulnerability compared to the agriculture sector.

In summary we can conclude that there are different rationales in the different sectors, leading to differing expectations. The clear group or sector differences from the regressions analyses indicate that sectors share beliefs and "grammar" within their sector. This we argue strengthens an argument for currently different socio-technical regimes $[29,39]$ between the biosectors in Norway.

These socio-technical regimes also indicate potential path-dependencies and lock-in relating to the future and new solutions, like the bioeconomy would entail. While some sectors have positive views and expectations towards a future bioeconomy, others are more reluctant. One of the explanations as discussed above, is differing expectations from the government, and differing economic frameworks. We argue that especially the agriculture, research and development, and transport, retail and distribution regimes need particular coordination and attention in the further long-term planning and management towards a transition to a sustainable bioeconomy.

Our analyses give some indications of how to overcome these path-dependencies. Cooperation, as an included variable, gave a very strong model improvement, together with attitudes towards nature. The need for cooperation across sectors is stressed in transition management theory and was also highlighted in the Government strategy for Bioeconomy [4].

\section{Conclusions}

A system shift, like a transition to the bioeconomy requires, depends on collaboration across disciplines, sectors and actors. Common goals and expectations, ambitions and visions will help drive a transition; however, research acknowledges that sectors and their stakeholders might be constrained by both path dependencies and lock-ins. In this paper, we have explored the expectations of biosector representatives regarding a future bioeconomy in Norway. We have identified how these expectations differ between sectors and how biological resources, cooperation across sectors and concern for sustainability are associated with these expectations and the sectors. Our analysis suggests that there is a strong sector-wise variation in expectations about the bioeconomy. Aquaculture, forestry and biotechnology sectors see themselves as important players in the future bioeconomy while, interestingly, agriculture plays down its role. With major developments and growth in the biotechnology and aquaculture sectors over the past decades, this finding might be in line with policy, industry and research expectations. In addition, forestry has been launched as a potentially very interesting contributor in the bioeconomy, not only when it comes to production of volumes of biomass for energy production in substitution for fossil oil, but also as potential for feed and food products and medical use. Knowledge about sectors' expectations at an early phase can be useful for policy planning and transition management, and also for the businesses themselves. In this study, we have reached out to known (NACE-Coded) sectors with connection to biomass, either through production, processing or use, in a study that to our knowledge never has been done to this extent. The particular group that 
responded can be assumed to identify themselves as part of the bioeconomic future. A total picture of the future "bioeconomists" is still to be drawn. Further research is needed to explore and identify the different elements of this new socio-technical regime, to understand barriers and potentials to the bioeconomy. A glimpse of the future has in this paper been identified through the expectations of some representatives of the current Norwegian biosectors to further assist policy planning and transition management regarding the bioeconomy. While possible futures can be accessed through more formal exercises as e.g., foresight scenario development, more informal studies of expectations can potentially inform these foresight exercises [50] (p. 779) regarding both types of stakeholders to be included in the planning and which topics need particular attention. More research, innovation and business activities in the forthcoming years will tell us how these expectations are part of the future transformations needed in a socio-technical transformation of the economy.

Acknowledgments: We would like to thank Brit Logstein, Rob Burton, Alexander Krogsrud Thanem and Magnar Forbord for contributions on the survey and useful comments and editors and reviewers of Sustainability for critical comments and suggestions that have improved the paper substantially. We would also like to thank the Research Council of Norway (Biosmart project No. 244608) for funding that enabled us to undertake this study.

Author Contributions: Lillian Hansen and Hilde Bjørkhaug conceived and designed the research; Lillian Hansen undertook the primary research and analysis of the data based on data from the Biosmart project. Hilde Bjørkhaug contributed particularly on Sections 1.1 and 4. Both authors read and approved the final manuscript.

Conflicts of Interest: The authors declare no conflict of interest.

\section{References}

1. Bugge, M.M.; Hansen, T.; Klitkou, A. What is the bioeconomy? A review of the literature. Sustainability 2016, 8,691 .

2. Swinnen, J.; Riera, O. The global bio-economy. Agric. Econ. 2013, 44, 1-5. [CrossRef]

3. Sheppard, A.W.; Gillespie, I.; Hirsch, M.; Begley, C. Biosecurity and sustainability within the growing global bioeconomy. Curr. Opin. Environ. Sustain. 2011, 3, 4-10. [CrossRef]

4. The Norwegian Government, Kjente Ressurser-Uante Muligheter. Regjeringens Bioøkonomistrategi. 2016. Available online: https://www.regjeringen.no/contentassets/32160cf211df4d3c8f3ab794f885d5be/nfd_ biookonomi_strategi_uu.pdf (accessed on 29 November 2016).

5. McCormick, K.; Kautto, N. The bioeconomy in Europe: An overview. Sustainability 2013, 5, $2589-2608$. [CrossRef]

6. Zilberman, D.; Kim, E.; Kirschner, S.; Kaplan, S.; Reeves, J. Technology and the future bioeconomy. Agric. Econ. 2013, 44, 95-102. [CrossRef]

7. Birch, K. Emergent imaginaries and fragmented policy frameworks in the Canadian bio-economy. Sustainability 2016, 8, 1007. [CrossRef]

8. Confederation of Norwegian Enterprise (NHO). Mot bioøkonomien. In Næringslivets Hovedorganisasjon; NHO: Oslo, Norway, 2016.

9. Grønn Konkurransekraft. Regjeringens Ekspertutvalg for Grønn Konkurransekraft. 2016. Available online: http://www.gronnkonkurransekraft.no/files/2016/10/Strategi-for-gr\%C3\%B8nnkonkurransekraft.pdf (accessed on 1 November 2016).

10. European Commission (EC). Innovating for Sustainable Growth: A Bioeconomy for Europe; European Commission, Directorate-General for Research and Innovation: Brussels, Belgium, 2012; Available online: http:/ /bookshop.europa.eu/en/innovating-for-sustainable-growth-pbKI3212262/ (accessed on 1 November 2016).

11. EC. Bio-Based Economy for Europe: State of Play and Future Potential—Part 1: Report on the European Commission's Public On-Line Consultation. Available online: https:/ /ec.europa.eu/research/consultations / bioeconomy/bio-based-economy-for-europe-part1.pdf (accessed on 1 November 2016).

12. Staffas, L.; Gustavsson, M.; McCormick, K. Strategies and policies for the bioeconomy and bio-based economy: An analysis of official national approaches. Sustainability 2013, 5, 2751-2769. [CrossRef]

13. European Commission (EC). Sustainable Agriculture, Forestry and Fisheries in the Bioeconomy-A Challenge for Europe. 4th SCAR Foresight Exercise. 2015. Available online: http://ec.europa.eu/research/ scar/pdf/feg4-draft-15_may_2015.pdf (accessed on 4 October 2016). 
14. Goven, J.; Pavone, V. The bioeconomy as political project: A polanyian analysis. Sci. Technol. Hum. Values 2015, 40, 302-337. [CrossRef]

15. Nadasdy, P. Reevaluating the co-management success story. Arctic 2003, 56, 367-380. [CrossRef]

16. Murphy, J.; Gouldson, A. The missing dimension in EU environmental technology policy. Eur. Environ. 1995, 5, 20-26. [CrossRef]

17. Kitchen, L.; Marsden, T. Constructing sustainable communities: A theoretical exploration of the bio-economy and eco-economy paradigms. Local Environ. 2011, 16, 753-769. [CrossRef]

18. Christoff, P. Ecological modernisation, ecological modernities. Environ. Politics 1996, 5, 476-500. [CrossRef]

19. Hajer, M.A. The Politics of Environmental Discourse: Ecological Modernization and the Policy Process; Clarendon Press: Oxford, UK, 1995.

20. Smith, A.; Stirling, A.; Berkhout, F. The governance of sustainable socio-technical transitions. Res. Policy 2005, 34, 1491-1510. [CrossRef]

21. Voß, J.-P.; Bornemann, B. The politics of reflexive governance: Challenges for designing adaptive management and transition management. Ecol. Soc. 2011, 16, 9. [CrossRef]

22. Avelino, F.; Rotmans, J. Power in transition: An interdisciplinary framework to study power in relation to structural change. Eur. J. Soc. Theory 2009, 12, 543-569. [CrossRef]

23. Borup, M.; Brown, N.; Konrad, K.; Van Lente, H. The sociology of expectations in science and technology. Technol. Anal. Strateg. Manag. 2006, 18, 285-298. [CrossRef]

24. Brown, N.; Michael, M. A sociology of expectations: Retrospecting prospects and prospecting retrospects. Technol. Anal. Strateg. Manag. 2003, 15, 3-18. [CrossRef]

25. Gordon, T.J.; Glenn, J.C.; Jakil, A. Frontiers of futures research: What's next? Technol. Forecast. Soc. Chang. 2005, 72, 1064-1069. [CrossRef]

26. Schot, J.; Rip, A. The past and future of constructive technology assessment. Technol. Forecast. Soc. Chang. 1997, 54, 251-268. [CrossRef]

27. Kemp, R.; Schot, J.; Hoogma, R. Regime shifts to sustainability through processes of niche formation: The approach of strategic niche management. Technol. Anal. Strateg. Manag. 1998, 10, 175-198. [CrossRef]

28. Geels, F.W. Technological transitions as evolutionary reconfiguration processes: A multi-level perspective and a case-study. Res. Policy 2002, 31, 1257-1274. [CrossRef]

29. Geels, F.W. From sectoral systems of innovation to socio-technical systems. Res. Policy 2004, 33, 897-920. [CrossRef]

30. Berkhout, F.; Smith, A.; Stirling, A. Socio-technological regimes and transition contexts. In System Innovation and the Transition to Sustainability: Theory, Evidence and Policy; Edward Elgar: Cheltenham, UK, 2004; pp. 48-75.

31. Geels, F.W. Technological Transitions and System Innovations: A Co-Evolutionary and Socio-Technical Analysis; Edward Elgar Publishing: Northampton, MA, USA, 2005.

32. Trist, E. The Social Engagement of Social Science, Volume 1: A Tavistock Anthology: The Socio-Psychological Perspective; University of Pennsylvania Press: Philadelphia, PA, USA, 1990.

33. Griffith, T.L.; Dougherty, D.J. Beyond socio-technical systems: Introduction to the special issue. J. Eng. Technol. Manag. 2001, 18, 207-218. [CrossRef]

34. Werner, R. New rules of sociological method: Rethinking technology studies. Br. J. Sociol. 1997, 48, $171-191$.

35. Centeno, M.A. The new Leviathan: The dynamics and limits of technocracy. Theory Soc. 1993, 22, $307-335$. [CrossRef]

36. Marsden, T. Towards a real sustainable agri-food security and food policy: Beyond the ecological fallacies? Political Q. 2012, 83, 139-145. [CrossRef]

37. Kleinschmit, D.; Lindstad, B.H.; Thorsen, B.J.; Toppinen, A.; Roos, A.; Baardsen, S. Shades of green: A social scientific view on bioeconomy in the forest sector. Scand. J. For. Res. 2014, 29, 402-410. [CrossRef]

38. Valseth, M.S. Innovation Norway supporting the development of an algae industry in Norway. In Proceedings of the Workshop, Nordic Algae Network and Blue Bio, Aas, Norway, 15 November 2012.

39. Geels, F.W. The multi-level perspective on sustainability transitions: Responses to seven criticisms. Environ. Innov. Soc. Transit. 2011, 1, 24-40. [CrossRef]

40. Dosi, G. Technological paradigms and technological trajectories: A suggested interpretation of the determinants and directions of technical change. Res. Policy 1982, 11, 147-162. [CrossRef]

41. Rip, A.; Kemp, R. Technological Change; Battelle Press: Brighton, UK, 1998. 
42. Verbong, G.P.J.; Geels, F.W. Exploring sustainability transitions in the electricity sector with socio-technical pathways. Technol. Forecast. Soc. Chang. 2010, 77, 1214-1221. [CrossRef]

43. Geels, F.W. Foundational ontologies and multi-paradigm analysis, applied to the socio-technical transition from mixed farming to intensive pig husbandry (1930-1980). Technol. Anal. Strateg. Manag. 2009, 21, 805-832. [CrossRef]

44. Grin, J.; Rotmans, J.; Schot, J. Transitions to Sustainable Development: New Directions in the Study of Long Term Transformative Change; Routledge: New York, NY, USA, 2010.

45. De Haan, J.H.; Rotmans, J. Patterns in transitions: understanding complex chains of change. Technol. Forecast. Soc. Chang. 2011, 78, 90-102. [CrossRef]

46. Geels, F.W.; Schot, J. Typology of sociotechnical transition pathways. Res. Policy 2007, 36, 399-417. [CrossRef]

47. Loorbach, D. Transition Management: New Mode of Governance for Sustainable Development; Dutch Research Institute for Transitions (DRIFT): Rotterdam, The Netherlands, 2007.

48. Rotmans, J.; Kemp, R.; van Asselt, M. More evolution than revolution: Transition management in public policy. Foresight 2001, 3, 15-31. [CrossRef]

49. Palavicino, C.A.; Konrad, K. Foresight as a Specific Mode of Governing Expectations: (Initial) Implications. 2012. Available online: http://scholar.googleusercontent.com/scholar?q=cache:uvGDjukUJA4J:scholar. google.com/+.+Foresight+as+a+specific+mode+of+governing+expectations:+\&hl=no\&as_sdt=0,5 (accessed on 4 October 2016).

50. Van Lente, H. Navigating foresight in a sea of expectations: Lessons from the sociology of expectations. Technol. Anal. Strateg. Manag. 2012, 24, 769-782. [CrossRef]

51. Van Lente, H. Promising technology. In the Dynamics of Expectations in Technological Developments; Enschede: Delft, The Netherlands, 1993.

52. Van Lente, H.; Bakker, S. Competing expectations: The case of hydrogen storage technologies. Technol. Anal. Strateg. Manag. 2010, 22, 693-709. [CrossRef]

53. Guice, J. Designing the future: The culture of new trends in science and technology. Res. Policy 1999, 28, 81-98. [CrossRef]

54. Foucault, M. The Archaeology of Knowledge and the Discourse of Language; Pantheon Books: New York, NY, USA, 1972.

55. Woolgar, S. Reconstructing man and machine: A note on sociological critiques of cognitivism. In the Social Construction of Technological Systems: New Directions in the Sociology and History of Technology; The MIT Press: Cambridge, MA, USA, 1987; pp. 311-328.

56. Eurostat. NACE. Rev 2 Statistical Classification of Economic Activities in the European Community; Office for Official Publications of the European Communities: Luxembourg, 2008.

57. Gail, M.H. Bias from Nonresponse. In Encyclopedia of Biostatistics; John Wiley \& Sons, Ltd.: Chichester, UK, 2005.

58. Aaberge, R.; Laake, P. Om statistiske teoriar for tolking av data. Tidsskrift Samfunnsforskning 1984, 25, $165-186$.

59. Truffer, B.; Voß, J.-P.; Konrad, K. Mapping expectations for system transformations: Lessons from Sustainability Foresight in German utility sectors. Technol. Forecast. Soc. Chang. 2008, 75, 1360-1372. [CrossRef]

60. Konrad, K.; Truffer, B.; Voß, J.-P. Multi-regime dynamics in the analysis of sectoral transformation potentials: evidence from German utility sectors. J. Clean. Prod. 2008, 16, 1190-1202. [CrossRef]

61. Geels, F.; Raven, R. Non-linearity and expectations in niche-development trajectories: Ups and downs in Dutch biogas development (1973-2003). Technol. Anal. Strateg. Manag. 2006, 18, 375-392. [CrossRef]

62. Lente, H.V.; Rip, A. Expectations in Technological Developments: An Example of Prospective Structures to Be Filled in by Agency; Walter de Gruyter: Berlin, Germany, 1998.

63. Brown, N.; Rappert, B.; Webster, A. Contested Futures: A Sociology of Prospective Techno-Science; Ashgate Pub Limited: Aldershot, UK, 2000.

64. Falk-Andersson, J.; Magnar, F.; Birger, V. Biogical Resources and Production in Forestry, Agriculture, Fisheries and Aquaculture across Norway; NORUT Northern Research Institute AS: Tromso, Norway, 2016.

65. Farsund, A.A. Norsk jordbruk i krysspress mellom nasjonal og internasjonal politikk. Norsk Statsvitensk. Tidsskr. 2014, 2, 85-107.

66. OECD. Agricultural Policy Monitoring and Evaluation 2016; OECD Publishing, The Organisation for Economic Co-Operation and Development: Paris, France, 2016. 
67. Almås, R. Omstart_Forslag til ein ny Landbrukspolitkk; Snøfugl Forlag: Melhus, Norway, 2016.

68. Brandlistuen, E. Landbruket, Fisket og WTO. Analyse av Landbruks- og Fiskerisektoren og de Forskellige Forhandlingsposisjonene i WTO, in Institutt for Statsvitenskap; Universitetet i Oslo: Oslo, Norway, 2005.

69. Norsk bioenergiforening (NOBIO)r. Årsmelding 2011. In Bioenergi; NOBIO: Oslo, Norway, 2012; Available online: http://nobio.no/upload_dir/pics/media/bioenergi/Bioenergi-3-2012.pdf (accessed on 15 July 2016).

70. Transport \& Environment (TE). Globiom: The Basis for Biofuel Policy Post-2020; Transport \& Environment: Burssels, Belgium, 2016; Available online: https://www.transportenvironment.org/publications/globiombasis-biofuel-policy-post-2020 (accessed on 1 October 2016).

71. Worldfish Center. Working Paper-Aquaculture, Fisheries, Poverty and Food Security 2011; Worldfish Center: Penang, Malaysia, 2011.

72. Kafle, G.K.; Kim, S.H.; Sung, K.I. Ensiling of fish industry waste for biogas production: A lab scale evaluation of biochemical methane potential (BMP) and kinetics. Bioresource Technol. 2013, 127, 326-336. [CrossRef] [PubMed]

73. Laksefakta. Hva er i Fôret til Laksen? 2016. Available online: https://laksefakta.no/hva-spiser-laksen/hvaer-i-foret-til-laksen/ (accessed on 1 October 2016).

74. Mohan, S.V.; Nikhil, G.N.; Chiranjeevi, P.; Nagendranatha Reddy, C.; Rohit, M.V.; Naresh Kumar, A.; Sarkar, O. Waste biorefinery models towards sustainable circular bioeconomy: critical review and future perspectives. Bioresource Technol. 2016, 215, 2-12. [CrossRef] [PubMed]

75. Borregaard. Ivesterer 63 Millioner Kroner i Bioetanol og Biogass. 2016. Available online: http://www. borregaard.no/Nyheter/Investerer-63-millioner-kroner-i-bioetanol-og-biogass /(language)/nor-NO (accessed on 1 October 2016).

76. Cesaro, A.; Belgiorno, V. Combined biogas and bioethanol production: Opportunities and challenges for industrial application. Energies 2015, 8, 8121-8144. [CrossRef]

77. Gonela, V.; Zhang, J. Design of the optimal industrial symbiosis system to improve bioethanol production. J. Clean. Prod. 2014, 64, 513-534. [CrossRef]

78. Framstad, E.; Økland, B.; Bendiksen, E.; Bakkestuen, V.; Blom, H.; Brandrud, T.E. Evaluering av Skogvernet $i$ Norge; NINA-Norsk institutt for naturforskning: Oslo, Norway, 2002.

79. Sabima, W.A. Innspill til Regjeringens Bioøkonomistrategi; Steel, N.J., Ed.; WWF and Sabima: Oslo, Norway, 2015.

80. Naturvernforbundet. Innspill til Bioøkonomistrategi; Haltbrekken, L., Ed.; Naturvernforbundet: Oslo, Norway, 2015.

81. Holtsmark, B. Use of Wood Fuels from Boreal Forests Will Create a Biofuel Carbon Debt with a Long Payback Time Discussion Papers; Statistics Norway: Oslo, Norway, 2010; Available online: https://brage.bibsys.no/xmlui/ handle/11250/180591 (accessed on 3 November 2016).

82. Follo, G. Eiendomsoverbyggende Samarbeid for Skogeiere i Kystskogbruket-Utfordrende, Men Med Stort Potensiale. In Norsk Senter for Bygdeforskning; Centre for Rural Research: Trondheim, Norway, 2014; Available online: http:/ / www.bygdeforskning.no/publikasjoner/eiendomsoverbyggende-samarbeid-for-skogeierei-kystskogbruket-utfordrende-men-med-stort-potensiale (accessed on 3 November 2016).

83. Statsskog. Hvem Eier Skogen? Available online: http://www.statskog.no/skogdrift/hvem-eier-skogen. html (accessed on 3 October 2016).

84. Sodano, V. Pros and Cons of the Bioeconomy: A Critical Appraisal of Public Claims through Critical Discourse Analysis. In Proceedings of the 2013 Second Congress, Parma, Italy, 6-7 June 2013.

(c) 2017 by the authors. Licensee MDPI, Basel, Switzerland. This article is an open access article distributed under the terms and conditions of the Creative Commons Attribution (CC BY) license (http://creativecommons.org/licenses/by/4.0/). 